Wu, Junjie, Zhu, Jinyu, Gold, Jeff ORCID:

https://orcid.org/0000-0003-0289-6712 and Fang, Hong (2018) Lending facilities versus banking service: unbalanced bank lending to SMEs in China. International Journal of Business and Globalisation, 20 (3). pp. 328-353.

Downloaded from: http://ray.yorksj.ac.uk/id/eprint/2613/

The version presented here may differ from the published version or version of record. If you intend to cite from the work you are advised to consult the publisher's version:

Research at York St John (RaY) is an institutional repository. It supports the principles of open access by making the research outputs of the University available in digital form. Copyright of the items stored in RaY reside with the authors and/or other copyright owners. Users may access full text items free of charge, and may download a copy for private study or non-commercial research. For further reuse terms, see licence terms governing individual outputs. Institutional Repository Policy Statement

\title{
RaY
}

Research at the University of York St John

For more information please contact RaY at ray@yorksj.ac.uk 


\title{
Lending facilities versus banking service - unbalanced bank lending to SMEs in China
}

$$
\text { Junjie } \mathrm{Wu}^{\mathrm{a}} \dagger \text {, Jinyu Zhu }{ }^{\mathrm{b}} \text {, Jeff Gold }{ }^{\mathrm{c}} \text {, }
$$

${ }^{\mathrm{a}}$ Leeds Business School, Leeds Beckett University, Leeds, UK

${ }^{\mathrm{b}}$ School of Accounting, Yunnan University of Finance and Economics, Kunming, China

${ }^{\mathrm{c}}$ York Business School, York St John University, UK

†Correspondence email: j.wu@leedsbeckett.ac.uk

\section{Lending facilities versus banking service: unbalanced bank lending to SMEs in China}

\begin{abstract}
This paper examines gaps in bank lending and services to SMEs in China, the problem of productive SME-bank relationships and the reasons behind these gaps. Specifically it distinguishes between lending facilities and lending services in order to highlight an imbalance in the current banking context for Chinese SMEs. It combines data from Berry (2006) with own matching data in China, drawing on Berger and Udell's (2006) conceptual framework of credit availability. This study adopts stylised comparisons with Germany, the UK and the USA, and Hong Kong. The results reveal that China has developed a banking infrastructure which is equivalent to comparable developed countries. However China is deficient with regard to the quality of bank services. The results are discussed in the context of government policies, the financial infrastructure, SME credit availability, and the intricacies of the SME-bank relationship in China.
\end{abstract}

Key words: SME financing, bank lending, SME-bank relationship, China 


\section{Introduction}

Since embarking on economic reform and opening in 1978, China has maintained an astonishing rate of economic development. Over the decades, China has pursued an incremental and experimental approach to its development and transition policy, focusing initially on the easiest areas of reform to implement (Dana, 2002). This has meant that some major areas of challenging reform have been left incomplete until relatively late and this includes banking reform. There has been a significant increase in the numbers of organizations offering banking services, e.g. by 2013 banking was diversified with total assets of RMB151 trillion and 3,747 financial institutions ${ }^{1}$ (CBRC, 2013). However, the government still ultimately controls the banking sector and interferes in the process of regulation and in infrastructure provision. Moreover, despite a formal commitment to encourage the development of smaller non-state-owned banks, actual policy still tends to perpetuate the dominance of large state-owned banks. This macro environment has had consequences for the relation between banking and Small and Medium-sized Enterprises (SMEs) in spite of the progress that has been made in banking reform.

In order to explore the consequences for SMEs of this macro environment this paper takes a nation-based comparative approach. It adapts data from Berry (2006) and combines this with subsequent matching research in China. The comparators are the UK, USA, Germany, and Hong Kong. Each provides a different perspective from which to consider issues for China. The USA and the UK comprise an Anglo-American approach to governance that has been China's primary benchmark in its formal approach to banking reform. However, the AngloAmerican approach is one rooted in broad and highly liquid capital markets. China shares with Germany a more bank dominated financial system. Moreover, German banking is

\footnotetext{
${ }^{1}$ Including 3 state policy banks, 5 large/national commercial banks (4 state-owned), 12 joint stock banks, 42 foreign bank subsidiaries, 144 city commercial banks, 337 rural commercial banks, 2,074 Rural credit cooperative banks/credit agents and 1,130 others.
} 
characterised by relationship lending, rather than distanced transaction lending, and this can be meaningfully compared to Chinese guanxi lending. Finally, Hong Kong provides a useful geographically proximate point of intermediate comparison based on the combination of its historically derived UK-style banking sector but close commercial, political and cultural connection with China. In summary, the aim of this paper are to identify gaps in China in bank lending and services to SMEs. We will consider the problem of productive SME-bank relationships and investigate reasons for the problem, drawing on Berger and Udell (2006)’s conceptual framework of SME credit availability concerning the link between government policies and national financial structures and the mediation of lending technologies.

The results reveal that Chinese SMEs now have multiple and diversified bank relationships and use a wide range of services provided by different types of banks and interact with those banks in a variety of ways. This indicates that China has developed a banking infrastructure that is, in terms of its potential for SME support, formally equivalent to comparable developed countries. However with regard to the quality of bank services i.e. the competence of bank staff and their understanding of SME business, as expressed through SME satisfaction with their bank and SME credit availability, China is as yet deficient. These results are placed in the context of China's macro lending environment, with reference to Berger and Udell and related subsequent empirical research.

The structure of the paper proceeds as follows: first, to provide relevant context, the key stylised features of the institutional structure and lending infrastructure are briefly set out, with reference then to SMEs, of each of the comparator countries; followed by methodology, data analysis and further discussion of the issues. 


\section{Financial institution structure and lending infrastructure with reference to SMEs in the comparator countries}

We provide a brief review of the context of the banking system in each surveyed country suggesting that Germany, the UK \& USA, and Hong Kong each have certain characteristics relevant to China's financial institutional structure and also lending infrastructure. As such, the use of a comparative approach is one that provides significant insight despite that China is in some respects also a unique case in terms of bank lending to SMEs and the bank-SME relationship.

The significance of long term and close banking relationships in the German system

Germany is well known for its export oriented and extraordinarily successful manufacturing sector. This sector is founded on quality, reliability, the continual pursuit of product innovation, and the use of advanced technology where applicable in the production process. A key component in the success of the manufacturing sector is the Mittelstand firms (The Economist, 2012). ${ }^{2}$ The Mittelstand are small and medium sized enterprises, often family owned, typically with thin management structures but highly technically qualified staff, and where the firms are often clustered around a major university, and close to significant larger firms. They thus benefit from external economies of scale if they are end-product producers, but also simple proximity advantages if they are part of supply chains. The other widely recognized aspects of the success of Germany’s Mittelstand are their banking relationships.

Research on the German banking system and SMEs (Quack and Hildebrandt, 1995; Harhoff and Körting, 1998; Elsas and Krahnen, 1998; Lehmann and Neuberger, 2001; Krahnen and

\footnotetext{
2 ‘Why doesn’t France have a Mittelstand?’ The Economist, October 20 2012.
} 
Elsas, 2004; Ongena et al., 2012) consistently reports that SMEs benefit from longstanding and personalised relations with a single bank and often a single designated individual or team of representatives of that bank - this is typically termed 'relationship lending'. This relationship lending is executed in a context where banks offer finance at relatively low interest rates (against a benchmark for comparable contemporary rates in other states) and over long periods. So, there is long term bank financing for capital projects, as well as permanently available and accommodative overdraft facilities to meet cash flow variations. The net result is a reduction in information asymmetry between the bank and the SME, a situation of trust, reducing the exposure of the bank to non-performing loans, and simultaneously, providing an enduring basis for financial stability as a springboard for business success. As such, the failure rate of SMEs in Germany is relatively low by international standards. ${ }^{3}$ Germany seems to exhibit highly developed lending services. Its lending infrastructure is also one with a primary focus on banking as a source of productive investment.

The German banking system has evolved over the decades with some banks following the universal model and taking on more commercial roles in capital markets etc. This is delivered through a complex web of different varieties of banks on different scales. ${ }^{4}$ However, the core banking actor within the infrastructure is the Hausbank (Housebank), which provides a transmission point for government support to SMEs through an available supply of subsidised

\footnotetext{
${ }^{3}$ http://ec.europa.eu/DocsRoom/documents/16344/attachments/13/translations/en/renditions/native, accessed 29/10/16.

${ }^{4}$ One might describe the overall banking sector as diverse, encompassing commercial banks, savings banks, cooperative banks and development banks (Quack and Hildebrandt, 1995; Kakes and Sturm, 2002). The commercial bank sector consists of large commercial banks (e.g. Deutsche Bank, Commerzbank, Dresdner Bank, Hypo-Vereinsbank), regional banks, private banks and foreign bank branches. The savings bank sector which traditionally acts as public function (e.g. financing local investment) includes the Landesbanks (owned by different federal states) and saving banks (owned by local governments) but they are gradually involved in more and more commercial activities (Kakes and Sturm, 2002). The credit co-operative sector comprises of many small credit co-operatives (owned by individuals or firms) and regional co-operative institutions owned by their local credit co-operatives (Kakes and Sturm, 2002).
} 
loans and loan guarantees. The Hausbank provides a buffer between the state and lending into the economy that mitigates the potential for irrational or non-economically motivated distortions in credit rationing. Hausbank pass qualified loan applications to guarantee banks (Burgschaftsbanken), or development banks (for example, Kreditanstalt fur Wiederaufbau KfW), which are partially funded by the government (Mullineux, 1994) and can carry guarantees of up to 85\% (Berry, 2006). The Hausbank is the primary source of long term low cost lending to SMEs. They also provide additional backstops such as short-term liquidity insurance in situations of unexpected deterioration of SME client credit ratings (Elsas and Krahnen, 1998).

The Anglo-American framework: a capital market context

As in the German system, in the UK and USA SMEs are typically clients of a single primary lender and that lender is typically a bank (see Berry et al., 2004; Berry, 2006; Yeung et al., 2012). However, the nature of the relationship can be contrasted, in a stylised fashion, with that in the German case. Whilst some form of relationship lending is not unknown in the Anglo-American framework, lending to SMEs tends to be for shorter periods at higher interest rates, and is characterised as less personalised. The context of lending services differs from the German case: lending tends to be standardised and based more on formal credit scoring models and banks are more likely to act conservatively in term of balance sheet protection by more quickly withdrawing credit, either based on difficulties experienced by the individual SME, or based on a general adverse movement in the business cycle. The approach is more observably market driven and many decisions are now taken at a level beyond the branch, reducing the autonomy of the manager and any lending teams with the specialised task of dealing with particular SME clients. There is, for example, more of a focus on managing the breach of lending covenants. As such, the failure rate of SMEs tends to be 
higher in the Anglo-American framework. Moreover, developing relations with SMEs is not a primary focus of the banking system in the UK and USA.

As in the German case there have been persistent, though not overwhelmingly successful, attempts by the state to encourage financial support for SMEs. For example, two UK-wide initiatives have been the Enterprise Finance Guarantee (EFG) scheme and Enterprise Capital Funds (ECFs), which provide government loan guarantees and venture capital funds respectively. ${ }^{5}$ In the UK, the SME banking market is best described, based on the dominance of the four top tier banks, as a ‘complex oligopoly' (Heffernan, 2006 p.3109). Most SMEs bank with one of the big four and thus rely on high street banking (Hussain et al., 2006). In terms of the quality of lending services, many studies over a long period have highlighted serious concerns about the difficulties experienced by SMEs in obtaining loans and the dissatisfaction of SMEs with their banking relationships (Bolton, 1971; Fletcher, 1994; Cosh and Hughes, 2000; Collis and Jarvis, 2002; Singh and Kaur 2015). The business cycle sensitivity of lending relationships in the Anglo-American framework is also highlighted by research confirming general satisfaction with an SME's main service provider during the credit boom prior to the global financial crisis (Fraser, 2004).

The situation in the USA does exhibit some difference from the UK. The federally initiated Small Business Administration (SBA), created in 1953, has provided longstanding continuity in terms of institutional support for SMEs. The SBA works with other organisations (such as Small Business Investment Companies -SBICs) to aid, counsel, assist and protect the interests of small businesses. Empirical studies (OECD, 2003; Hagendorff et al., 2007; Scott and Dunkelberg, 2010) consistently suggest that US bank services to SMEs mainly operate at a

\footnotetext{
${ }^{5}$ http://www.ukbusinessgrants.org, access 03/07/13.
} 
local rather than a national level and that this market/deposit concentration leads to the development of long term relationships between banks and SMEs. Smaller banks in particular tend to develop 'relationship lending' characteristics with SMEs. Whilst acknowledging this it remains the case that the Anglo-American framework is quite different from the German framework.

The hybrid or mixed Hong Kong banking system

Hong Kong provides a useful geographically proximate point of intermediate comparison for China. This is because of its historically derived UK-style banking sector but close commercial, political and cultural connection with China. Hong Kong is situated on the south coast of China next to Guangdong province. Over 90\% of Hong Kong's population are the descendants of Cantonese-speaking immigrants, many of whom were refugees from either civil war or Communist rule. After the First Opium War (1839-1842), Hong Kong became a colony of the British Empire. It was ruled by Britain from the 19th century until 1997 when its sovereignty was returned to China. ${ }^{6}$ During that period Hong Kong established itself as a commerce port between China and the West, and as a corollary, as a centre of finance, initially for trade. As such, Hong Kong developed as a site of laissez-faire economy characterised by minimal government intervention, low bureaucracy and market competition (Schenk, 2002).

Hong Kong’s economic infrastructure, political culture and education system are often described as hybrid, an "East meets West”. ${ }^{7}$ China’s government has been particularly careful in acknowledging this hybridity, and has treated Hong Kong as a unique case within its newly extended borders. On $1^{\text {st }}$ July 1997, Hong Kong returned to China as a special administrative

\footnotetext{
${ }^{6}$ Except for a short period of Japanese occupation during the Pacific War, 1941-1945.

7 “24 hours in Hong Kong: Urban thrills where East meets West”, CNN news, March 8, 2009.
} 
region, under the principle of "one country, two systems" (Lin, 2001). The Hong Kong Reunification Ordinance (Kwan, 2006), establishes that Hong Kong’s market and banking system will remain effectively unchanged. This is part of a developmental strategy in which the rest of China is expected to absorb some practices and institutional forms from Hong Kong, whilst Hong Kong, in turn, is slowly assimilated with the mainland. Hong Kong has played a main role as a point of transmission for export oriented trade via Guangzhou, during a period in which Shanghai in particular has been developed as a complementary site for business and finance. As such, the lending facilities and banking services exhibited by Hong Kong's banking system are significant for China in terms of practical interactions and as a source to be emulated. All Chinese state owned banks now have branches in Hong Kong, and their assets proportion in overall Hong Kong banking assets has increased rapidly in recent years, for example from $9 \%$ in 2009 to $15 \%$ in $2013 .^{8}$

Hong Kong has ranked third or fourth in global measures of financial centres for more than half century. Three quarters of the world's hundred largest banks trade in Hong Kong (Lam and Burton, 2005). The local financial infrastructure is highly developed across all elements of banking and finance, and is also dense (Hong Kong is only 1,104 km²; Kwan, 2006). The infrastructure, moreover, encompasses small local banking with long historical antecedents in pre-revolutionary China, as well as significant larger organizations that emerged from the colonial period (e.g. Hang Seng Bank). Indigenous banks and institutions are popular among Cantonese and local firms and serve an important part in the mainstream banking sector.

SMEs and SME-bank relationships in Hong Kong are under-researched and reported. However, it is widely recognized that Hong Kong's financial sector is significantly

\footnotetext{
8 "Integration with mainland banking system: the opportunity and challenges Hong Kong banking sector facing”, The First Financial Daily newspaper (Diyicaijingribao, China), November 26, 2013.
} 
influenced by its British heritage (Schenk, 2002), and given Hong Kong’s economic, political and cultural connections to the mainland, the administrative region can provide a proximate point of intermediate comparison between China and the West in terms of lending facilities and banking services to SMEs.

Hong Kong's banking sector provides SMEs with a wide variety of sources of credit, creating choice and some competition. In this sense, the lending facilities are well developed. However, unlike the USA and UK, where SMEs tend to be dependent on a single bank in a marketized context and the German case where long term relational lending focused around a single bank is significant, SMEs are not loyal to a single bank. According to Lam and Burton (2005), multiple relationships and frequent switching with low costs between banks are normal in Hong Kong and a low proportion (only about a quarter) of SMEs use a single bank. One might say that the Hong Kong banking sector incorporates some of the features exhibited by other banking systems but does so in a unique circumstance. Specifically, switching may be a signal of both push and pull factors. It may be a consequence of effective competition based on high-quality lending services, terms and conditions. However, it may also be a signal of poor quality lending services - a failure of the bank to inculcate loyalty in a context where other choices exist. Given the typically high transaction costs involved in shifting between banks and given that transaction costs can be more significant for SMEs than larger firms, it seems likely (and both research and anecdotal evidence tends to support this) that it is dissatisfaction (a push factor), that drives this shifting. As a result, banks may wish to work to improve service quality since this is found to have a strong association with the durability of the business relationship (Lam and Burton, 2006). 
Hong Kong also shares with Germany, the UK and USA some degree of support by government for SME finance. The Hong Kong Monetary Authority (HKMA, the bank regulator) and the Department of Trade and Industry provide significant support in terms of funding and business advice to SMEs through four schemes: the loan guarantee scheme, the export marketing fund, the training fund, and the development fund. Furthermore, the Commercial Credit Reference Agency (CCRA), authorised by the HKMA, gathers SME credit information on behalf of the banks, provides SMEs with better access to finance and minimises the risk of default (Berry, 2006).

Despite having historical, political and cultural connections to the mainland, the fundamental difference exhibited by the financial system in Hong Kong compared to China is in the aspects of ownership and marketization, measured by the extent of government control and intervention. In Hong Kong, the government does not control financial resource allocation through bank ownership, and banking regulation is kept to a minimum in accordance with the tenets of a laissez-faire economy. As such, Hong Kong SMEs do not experience the same politically influenced context as mainland SMEs in terms of banking relations. In China, state-owned banks dominate the lending infrastructure. Moreover, the substantive relations of SMEs tend to be different. The phenomenal success of the Chinese economy over the last two decades means that today the majority of Hong Kong SMEs are service-oriented firms operating as sub-contractors to larger organizations in China. China’s SMEs, however, tend to be more closely integrated into the supply chains of those larger organizations, and many of those are State-Owned Enterprises (SOEs) (Siu et al., 2006). As such, China SMEs face the simultaneous challenge of accessing lending services from a banking context dominated by state-owned banks and of dealing with SOE hierarchies. Both may involve noncommercial considerations and both mean that political capital (including that expressed in a 
culturally specific form as guanxi, see below) is an important feature of effective business conduct. This can result in problems for SMEs in China that are then expressed in the banking services environment.

\section{Chinese banking system in the socialist market economy}

As noted earlier, China is a unique case in terms of bank lending to SMEs and the bank-SME relationship because its banking system operates in a mixed market economy (the socialist market economy). It is now distanced from a traditional socialist planned economy but not yet a fully realized capitalist market economy. Significantly its banking system is still heavily influenced by the state, and particularly through the dominance of the large state-owned banks. This characteristic has discriminated against SMEs in terms of the greater priority placed on larger organizations by the banks and in terms of the more limited capacity of SMEs to develop relationships with banks that are oriented in this way (Dana, 2013). Superficially, this problem seems analogous to that confronted in the UK and US context. However, the reasoning here is different: it is the lack of relevant political capital and of guanxi that provides a major constraint for SMEs in China. This is a situation that has emerged through historical processes (Dana, 1999).

During 1949-78, China was a socialist planned economy. Its banking system mirrored that in the Union of Soviet Socialist Republics (USSR) and the People's Bank of China (PBOC) acted as a central bank and the main commercial bank. After economic reform began in 1978, centrally planned financial resource allocation was gradually reduced and local authorities started to have some freedom to decide usage of financial resources. Initial reform also created a "two tier" banking system: the PBOC, which functioned as a central bank, and 
four state owned commercial banks (SOCBs). ${ }^{9}$ In 1986, the first joint equity bank, the Bank of Communication (BOCOM) was established, and this was followed by new small and medium sized commercial banks mainly in regions and cities to provide localised bank services to firms and individuals. ${ }^{10}$ As such, the lending infrastructure in China has gradually diversified.

In 1994, an initiative to improve governance in the banking sector was begun. This followed significant pressure to normalise China's banking practices with recognized international standards as part of the initial process of applying to join the World Trade Organization (WTO). Concomitantly, China came under pressure to liberalise its banking sector and open it up to foreign bank participation (Yeung, 2009). China also formally abandoned credit planning for the SOCBs in 1998 (Zhang et al., 2012). State-imposed credit allocation systems create a potential for distortion in credit rationing, and also serve to maintain the dominance of these entities in the provision of bank services. Though formally abandoned the practice has had longstanding consequences for SMEs. In principle, however, the choices open to SMEs have greatly increased over the last 15 years. All SOCBs have formally adopted similar Anglo-American type corporate structures and are governed by a Board of Directors. This was intended to meet the requirements of a stock market listing. Banks have, as such, become in principle more transparent. After 2001 China joined the WTO, and foreign investment in China's commercial banks increased, improving the liquidity of those banks. In 2003, the principle of private ownership in the banking sector was finally accepted by the State Council (Fu and Heffernan, 2009) and the China Banking Regulatory Commission

\footnotetext{
${ }^{9}$ i.e. the Industrial and Commercial Bank of China (ICBC), the Agricultural Bank of China (ABC), the Bank of China (BOC) and the China Construction Bank (CCB).

${ }^{10}$ this group of new banks includes city commercial banks (CCBs), rural commercial banks (RCBs) and rural credit cooperative banks (RCCs) (Fu and Heffernan, 2009), though some of them (e.g. CCBs) largely owned by local governments.
} 
(CBRC) was established to regulate (alongside the PBC) and monitor the banking industry (Berger et al., 2009).

The actual situation of SMEs with respect to the availability of credit and the quality and availability of banking services is complex (Allen et al., 2005). SMEs are highly dependent on bank credit and services because stock and bond markets are as yet underdeveloped, highly volatile, and because SMEs lack the scale to meet the typical requirements for listing. Nearly $90 \%$ of firms external funding for SMEs derives from bank loans (Hou and Wang, 2013). As such problems within the banking system can cause a wide range of problems for SMEs. The Chinese banking system is still significantly influenced by the state. Despite changes, the state still holds the majority of equity shares for all SOCBs and thus remains the ultimate owner. The state still interferes in the allocation of credit both directly and indirectly as confirmed by Hou and Wang (2013), who note that the SOCBs continue to dominate in the system, despite growing diversity in terms of infrastructure provision. Moreover, other banks have good institutional reasons to mirror the behaviour of the SOCBs. The protection of private property rights is as yet historically new and weak. There is also a de facto recognition that scale affects political capital and this affects the credit worthiness of an organization on the basis of the capacity of that organization to bargain its way out of financial trouble. Furthermore, the credit application process remains highly bureaucratic and thus it makes sense to focus on larger scale lending as well as larger scale firms. It is, therefore, not unreasonable that all other banks in the system tend to also prefer to deal with larger firms and with the SOEs. As such, SMEs consistently find it difficult to obtain bank loans (Poutziouris et al., 2002; Podpiera, 2006; Wu et al., 2008) and are forced to borrow money at high interest rates via informal lenders (Wu, 2011). 
There is a clear problem of informality here in terms of the banking system and SMEs. The context differentiates Chinese relational lending from German relational lending. Discrimination against private firms and weak protection of private property rights worsen information asymmetry problems in bank lending to SMEs in China (Zhou, 2009). As a result, in order to mobilise critical resources, Chinese SME owners/managers are found to have a strong interest in investing in political capital. ${ }^{11}$ They do so through joining political organisations/networks (Zhang, 2008; Zhou, 2009). This membership can help increase access to influential figures such as political elites and bank managers, through their personal networks, and a form of relationship lending can be facilitated. Significantly, the relationship is one that focuses on power more than it does on the forms of investment to be undertaken. Moreover, there is a problem of circularity, only the successful and/or well-connected can develop these networks and access its influence. For most ordinary SME owners/managers, their political capital investment is constrained to a more direct cultivation of relations with specific branch bank officers. SOCBs dominate and have links into the state bureaucracy. So SMEs also collude in the reproduction of the power and dominance of SOCBs. As a matter of pragmatism SMEs seem to prefer a relationship with SOCBs than with private banks.

As stated previously, relationship lending in Germany features a long term and stable relationship between SMEs and their house banks. This relationship is based on a formal contract backed by government legislation and underwritten by the existence of the state in a formal and distanced sense, where it is long-term commercial considerations that dominate. In contrast, relationship lending in China is often in the form of guanxi lending. Guanxi is a difficult cultural concept to translate into a non-Chinese context. It is often defined in AngloAmerican discourse as a form of social network influence or social capital, rooted in

\footnotetext{
${ }^{11}$ For example, legislative memberships of Communist Party (CP), the People's Congress (PC) and the People's Political Consultative Conference (PPCC).
} 
traditional Confucianism, Taoism and Buddhism (Yao and Yueh, 2009). It refers to an informal and complex inter-personal relationship, which contains many elements such as mutual commitment, loyalty, obligation and trust (Tan et al., 2009). Guanxi ties are commonly established among Chinese through dining and gift-given before any written contract is signed (Davies, 1995; Wong and Chan, 1999). In many respects it is a substitute for stronger dependence on formal law and on specific contracts, though it is also a way of gaining access to contractual opportunities. In the current Chinese context a reliance on guanxi may reflects institutional weakness (a social aspect), poor development of property rights and contract law (an economic aspect) and the motivations of individual personal gain (a psychological aspect). Though guanxi is not an alien concept in Hong Kong, it is not of the same order of significance.

The point highlighted here is that not only are SMEs not a major priority for the dominant actors in the banking system, they also lack significant guanxi that may enable them to challenge that situation. They do, however, have reasons to seek to engage in guanxi relations. The transitional nature of the current Chinese banking system differentiates China from the German, Anglo-American and Hong Kong banking systems. This kind of hybrid mixtures of public ownership and private initiative has developed in a rather different way than the German context. It creates the potential for distortions in credit rationing and also in terms of the institutional focus for supporting aspects of the economy through supporting potentially significant sectors of the business community (Newman et al., 2012; Yeung et al., 2012) ${ }^{12}$. There is also a blurring of the regulator and lender function in so far as the state remains active. There is the potential for unequal competition in the banking sector. The state

\footnotetext{
${ }^{12}$ For example in the UK, the Financial Services Authority (FSA) which is controlled by the government department (the UK Treasury) regulates the financial service sector but the government does not own commercial banks excluding some bail-out cases in unexceptional circumstances (e.g. UK government bailed out Lloyds and RBS in 2007-09 financial crisis).
} 
has a vested interest in maintaining the solvency of the SOCBs and the SOCBs also have guanxi. As such they enjoy preferential access to capital and experience lower interest rates compared to other banks in the system. ${ }^{13}$ This also serves to reproduce a focus on larger SOEs because lending to SOEs and to local government are reasons why the SOCBs are systemically significant.

\section{Research methodology}

The primary aim of this study is to explore the status of bank lending services in China to SMEs in the context of the comparators. In so doing this study adapts data from Berry (2006) and augments this with our own matching research in China. ${ }^{14}$ We delivered 1,000 questionnaires but intended to target 200 SME respondents to match Berry's respondent numbers in each country and finally collected 187 usable questionnaires. The analysis pattern followed that in Berry's work to facilitate comparison (see Tables 2, 4, 5, 6, 7 and 8). One may argue Berry's research was tied with a professional body however it is a standard research approach conducted by a professor in a UK university. One may also be tempted to infer that the initial 2006 data is now dated, reducing the relevance of the subsequent work. However, the point of the comparison is to construct a stylised and constructive contrast with contemporary trends in China in order to highlight issues in regard of China. As such, changes within the comparators since 2006 are largely beside the point. They are, however, noted where relevant.

The major divergence in method between own and Berry's work concerns the nature of the sample. Berry's work was based on a randomly selected sample and the questionnaire was

\footnotetext{
${ }^{13}$ For example, by the end of 2009, the four SOCBs had a market share of 51\% of total banking assets while CCBs and RCCs had $6.6 \%$ and $11.5 \%$ of respectively.

${ }^{14}$ The data and questions included in Berry's in relation to Spain and accountants were deliberately excluded in this paper to fit its own purpose.
} 
subsequently executed by telephone. China is geographically highly diverse in terms of economic and social development. It has a population of more than 1.2 billion and more than 50 million SMEs. Given these characteristics any viable small-scale research that applied a geographically undifferentiated random sample method ran the risk of being nonrepresentative of the population. To adjust for this possibility 3 representative geographies were targeted: Beijing (the capital of China representing a highly developed region), Hubei province (in the middle of China, representing a developed region) and Yunnan province (in the southwest of China, representing a less developed region). Berry’s questionnaire was then adapted by revising and adding questions to reflect China's regulatory context and personally delivered by local researchers in person or by email to owners/managing directors or financial managers of SMEs in the sample frame randomly selected from local company yellow pages in $2011^{15}$, with roughly balanced numbers in each regions. The format conformed to China's firm size classifications (designated in 2003) ${ }^{16}$ and categories of industries.

The measurement of SME size in other countries generally follows EU guidelines (i.e. below 250 employees) but categorizations vary in China across sectors. For example, maximum employee numbers of SMEs for wholesale are 200 while for construction are 3,000. The classification of industries is also different in China and some new categories were added to match official regulation and industry importance in the literature. ${ }^{17}$ Key information comparing Chinese respondents and those aggregated from comparator countries is shown in Table 1 . Table 1 suggests, in terms of size, $74 \%$ of Chinese respondents have employee numbers ranging from 50-3,000 whilst 75\% of respondents in other countries have a number

\footnotetext{
${ }^{15}$ As noted in the introduction Berry's data was published in 2006 and was collected before this date. It serves a stylised function here and is, as such, not anachronistic. The primary data was collected in 2011. Again, though the data is now 4 years old, the context in which it was collected and the insights it provides remain relevant. ${ }^{16}$ http://www.china.com.cn/chinese/PI-c/288809.htm

${ }^{17}$ For example, the information technology industry is increasingly important in China (Xiao, 2011).
} 
of employees below 50. With regard to industries, the respondents in other countries were mainly in production/manufacturing (33\%) and wholesale or retail (27\%), whilst Chinese respondents are spread evenly across sectors. In addition, about half of other countries’ SMEs operate locally whilst most of Chinese respondents do business beyond local markets. However, the proportion of Chinese SMEs operating across national boundaries is much lower than in other countries, $11 \%$ of Chinese firms operated internationally compared to $34 \%$ of those in other countries. 
Table 1: Comparison of demographic data of respondents

\begin{tabular}{|c|c|c|c|c|c|c|c|c|}
\hline \multicolumn{4}{|c|}{ Size measured by turnover } & \multicolumn{5}{|c|}{ Types of industry } \\
\hline \multicolumn{2}{|l|}{ China } & \multicolumn{2}{|l|}{ Others* } & \multicolumn{2}{|l|}{ China } & \multicolumn{3}{|l|}{ Others* } \\
\hline RMB $¥$ & $\%$ & Sterling $£$ & $\%$ & & $\%$ & & & $\%$ \\
\hline$<500,000$ & 4 & $<50,000$ & 13 & Agriculture & 2 & Agriculture & & 2 \\
\hline 500,000- 1 million & 12 & $50,000-250,000$ & 22 & $\begin{array}{l}\text { Production or } \\
\text { manufacturing }\end{array}$ & 21 & Production or manufacturing & & 31 \\
\hline 1 million- 5 million & 19 & $250,000-500,000$ & 15 & Construction & 7 & Construction & & 9 \\
\hline 5 million- 20 million & 19 & 500,000-1 million & 11 & Wholesale or retail & 10 & Wholesale or retail & & 27 \\
\hline 20 million- 50 million & 13 & 1 million- 5 million & 17 & Catering & 9 & Catering & & 2 \\
\hline $\begin{array}{l}50 \text { million- } 100 \\
\text { million }\end{array}$ & 23 & 5 million- 10 million & 12 & $\begin{array}{l}\text { Transport or } \\
\text { communications }\end{array}$ & 12 & Transport or communications & & 4 \\
\hline 100 million- 3 billion & 10 & $\begin{array}{l}10 \text { million- } 25 \\
\text { million }\end{array}$ & 10 & Finance or insurance & 4 & Property or finance & & 5 \\
\hline \multirow[t]{2}{*}{ Total } & \multirow[t]{2}{*}{100} & & 100 & Business services & 3 & Business services & & 15 \\
\hline & & & & Oil or chemicals & 14 & $\begin{array}{l}\text { Public admin, health \& } \\
\text { education }\end{array}$ & & 2 \\
\hline \multicolumn{4}{|c|}{ Size measured by employee numbers } & Information technology & 14 & Personal or leisure services & & 3 \\
\hline China & \multicolumn{2}{|c|}{ Others* } & $\%$ & Total & 100 & & & 100 \\
\hline Owner only & 1 & Owner only & 4 & & & & & \\
\hline $1-9$ & 4 & $1-9$ & 40 & \multicolumn{5}{|c|}{ Markets in which SMEs operate } \\
\hline $10-19$ & 4 & $10-19$ & 16 & \multicolumn{2}{|l|}{ China (main market) } & Others*(overlapped) & \\
\hline $20-49$ & 17 & $20-49$ & 19 & $\%$ & \multirow{2}{*}{\multicolumn{2}{|c|}{ Local }} & $\%$ & \\
\hline $50-99$ & 19 & $50-99$ & 10 & Local & & & 49 & \\
\hline $100-249$ & 21 & $100-249$ & 8 & Regional & \multicolumn{2}{|c|}{ Regional } & 35 & \\
\hline $250-499$ & 14 & $250-499$ & 3 & National & \multicolumn{2}{|c|}{ National } & 33 & \\
\hline $500-3,000$ & 20 & & & International & \multicolumn{2}{|c|}{ International } & 35 & \\
\hline Total & 100 & & 100 & Total & & & & \\
\hline
\end{tabular}




\section{Data analysis}

\subsection{Survey results categorized by component of the SME-bank relationship}

Single or multiple relationships

As noted in Section 2, whether SMEs are engaged in single enduring or shifting and multiple relationships with banks depends on context (see also Rajan, 1992; Thakor, 1996; Ongena and Smith, 2000; Berger et al., 2008; Haas et al., 2010). SMEs in the USA and UK tend towards dependency on a single bank for quite different reasons than is the case in Germany, whilst SMEs in Hong Kong tend more towards multiple relationships. This research places China closer to Hong Kong. Table 2 indicates that, whilst the results for comparators are consistent with that in the literature, China has the lowest percentage of single bank relationships (12\%) and the highest mean in terms of number of banking relationships (3.34).

Table 2: Comparison of number of banking relationships

\begin{tabular}{|c|c|c|c|c|c|}
\hline \multicolumn{3}{|c|}{ Number of banking relationships } & \multicolumn{3}{|c|}{ Average of relationships by country } \\
\hline & China (\%) & Others* (\%) & Country & $\begin{array}{c}\text { Single } \\
\text { relationship (\%) }\end{array}$ & $\begin{array}{l}\text { Mean number of } \\
\text { relationships }\end{array}$ \\
\hline 1 & 12 & 44 & China & 12 & 3.34 \\
\hline 2 & 26 & 19 & UK & 78 & 1.37 \\
\hline 3 & 27 & 18 & USA & 66 & 1.67 \\
\hline 4 & 12 & 8 & Germany & 39 & 2.15 \\
\hline 5 & 6 & 4 & Hong Kong & 30 & 1.85 \\
\hline $6-7$ & 9 & 3 & & & \\
\hline $8+$ & 9 & 3 & & & \\
\hline
\end{tabular}

One can disaggregate this finding further. In Section 2 it is noted that China's lending infrastructure had gradually diversified. This is reflected in Table 3, which indicates that SMEs have, formally at least, access to a wide variety of banks. This is equivalent to the variety available in the majority of modern economies. However, it is also noted in Section 2 that SOCBs dominate the lending landscape and benefit from privileged access to state 
support, which in turn provides them with a competitive market advantage (in terms of capital and interest rates) ${ }^{18}$ but also creates a sense of privileged access in terms of influence (based on guanxi). Table 3 (see also later subsections) supports these claims in so far as it is larger SMEs that tend to be clients of SOCBs. Large SMEs, defined as capitalised between Renminbi (RMB) 50 million and 3 billion, mainly have relationships with SOCBs (41.3\%), Additionally Section 2 suggests other banks tended to emulate the behaviour of the SOCBs and this is confirmed by the relative focus of joint-stock commercial banks (44.7\%) and foreign banks (77.8\%) on the larger SMEs. Smaller SMEs, meanwhile, tend to be clients of city commercial banks (42.9\%) and rural credit cooperatives (41.7\%). As such, the market appears to be informally segregated.

Table 3: Chinese sample banking types by firm size (measured by capital)

\begin{tabular}{lcccc}
\hline Types of banks & $\begin{array}{c}\text { RMB } \mathbf{z} \\
<5 \mathbf{m}\end{array}$ & $\begin{array}{c}\text { RMB¥ } \\
\mathbf{5 m}<\mathbf{5 0} \mathbf{~ m}\end{array}$ & $\begin{array}{c}\text { RMB¥ } \\
\mathbf{5 0 m}<\mathbf{3} \mathbf{~ b}\end{array}$ & $\begin{array}{c}\text { Row } \\
\mathbf{\%}\end{array}$ \\
\% within State-owned Commercial Banks & 25.7 & 33.0 & 41.3 & 100.0 \\
\% within Joint-Stock Commercial Banks & 29.1 & 26.2 & 44.7 & 100.0 \\
\% within City Commercial Banks & 42.9 & 33.8 & 23.3 & 100.0 \\
\% within Rural Credit Cooperatives & 41.7 & 29.1 & 29.2 & 100.0 \\
\% within Foreign Banks & 11.1 & 11.1 & 77.8 & 100.0 \\
\hline
\end{tabular}

Source: from own survey.

However, this situation is not static. The expansion and dominance of SOCBs has resulted in blanket coverage. There are SOCB branches/business offices in all cities, counties and towns in China (Chong et al., 2013). As such SOCBs now find themselves in locations where they are competing with other forms of bank, including city commercial banks and rural credit cooperatives. When these branches are physically distant from the headquarters, the holding banks may exercise little control, i.e. local branches have some freedom in granting loan

\footnotetext{
${ }^{18}$ Politically favoured SOCBs have better banking credit and access to favourable interest rates and as a result enjoy higher excess reserves ratios, deposit/loan ratios and lower loan/asset ratios (Jia, 2009).
} 
approvals (Berger and DeYoung, 2001). So although smaller SMEs may not be the priority of SOCBs in general, SOCBs can be gradually observed to be extending their coverage across the range of SMEs. As set out in Section 2, the SMEs also prefer this relationship, though not necessarily for purely commercial reasons (Zhou, 2009; Lu et al., 2012).

Combining insights from Tables 2 and 3, one might argue that SMEs in China may prefer multiple bank relationships in order to maximize credit access and minimize risks of sudden credit shortfalls. These reasons might partially explain why Chinese SMEs can, to some extent, overcome financial obstacles and cope with an imperfect banking system and maintain growth (Zhou, 2009; Yao and Yuch, 2009). However, the current form of the relation privileges the large and does so through the continued dominance of the SOCBs. This in turn creates a context for how "SOCBs are aggressively improving their services to compete with foreign banks in the highly lucrative market of private banking business in China” (Yeung et al., 2012, p.857). Despite the influence of joining the WTO, which is increasingly reflected in the lending infrastructure, it remains the case that the politics of banking and guanxi continue to inadvertently influence the Chinese SME-bank relationship.

\section{Banking services used}

Effective bank services provide multiple advantages. In general terms, using the lending services and other products of a given bank can enhance the SME-bank relationship. This is because communication is concentrated and the bank can become aware of the range of ways in which it can be of further service to the SME, further promoting the interchange of information and creating synergies that promote the cross-selling of other products and services (Santikian, 2014). Where this is effective trust is also created which then promotes 
enduring relations with lower transaction costs, all other things being equal (Morgan and Sheehan, 2015). Santikian's (2014) findings suggest that deposit and savings accounts, cashmanagement and financial service products are important drivers of a strong firm-bank relationship because banks can use information obtained from other cross-sold products to monitor borrower accounts (Norden and Weber, 2010). Such a strong relationship can perhaps also help both participants survive a crisis (Iyer and Puri, 2012). Furthermore, bank products and services used by SMEs are related to the country's macroeconomic and financial development (Ghosh, 2006). For example, Klapper finds, "factoring is larger in countries with greater economic development and growth and developed credit information bureaus” (2006, p.3111).

Table 4 sets out the bank services used by SMEs and suggests that Chinese SMEs have a much higher usage of all bank services (excluding a similar usage for current accounts) than their international counterparts.

Table 4: Comparison of banking serviced used

\begin{tabular}{|c|c|c|c|c|c|c|c|c|c|c|}
\hline & U્己 & 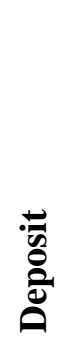 & 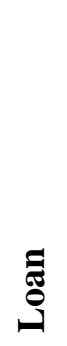 & 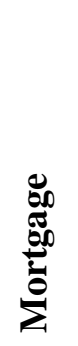 & 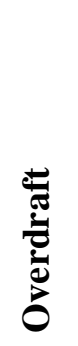 & 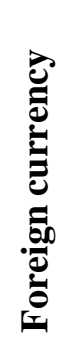 & 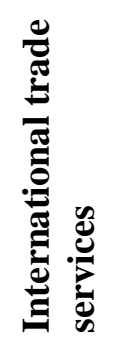 & 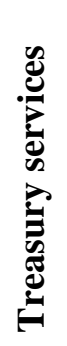 & 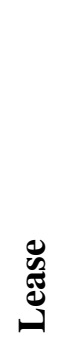 & 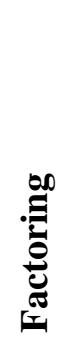 \\
\hline & $\%$ & $\%$ & $\%$ & $\%$ & $\%$ & $\%$ & $\%$ & $\%$ & $\%$ & $\%$ \\
\hline China & 99 & 92 & 91 & 71 & 52 & 52 & 52 & 57 & 54 & 52 \\
\hline $\mathrm{UK}^{*}$ & 98 & 68 & 31 & 11 & 48 & 34 & 19 & 20 & 29 & 11 \\
\hline USA* & 97 & 61 & 47 & 20 & 25 & 7 & 10 & 8 & 16 & 16 \\
\hline Germany* & 97 & 35 & 56 & 15 & 58 & 9 & 3 & 0 & 32 & 5 \\
\hline Hong Kong* & 98 & 84 & 49 & 27 & 52 & 74 & 39 & 25 & 27 & 29 \\
\hline
\end{tabular}


The most significant of these findings are context specific. The significantly high levels of access to foreign currency services and international trade services indicate that Chinese SMEs tend to be internationally engaged (hence also the figures for Hong Kong, though Germany seems anomalous here). ${ }^{19}$ The high levels of treasury services and mortgage access also indicate that Chinese SME owners also use their businesses as security for property and financial assets. This potentially makes banks a high risk if SME bank loans are defaulted. It might be one of reasons that Chinese banks have high non-performance loan rate. The relatively high uptake in all categories indicates that any potential competition for clients amongst Chinese banks is based on a wide variety of potential services, all of which SMEs are keen to access. The formal availability of these services again indicates that the lending infrastructure in China is now well developed. The quality of services, however, remains at issue.

\section{Bank communication channels}

In recent years a growing trend has been observed regarding bank's uptake of new communication technologies and platforms (e-mail, internet based service deployment etc). From the banks' point of view, these new communication channels reduce costs and provide pathways and systems that enable data collection to promote further services. Their uptake also enables banks to reduce or replace more traditional means of communication. However, empirical evidence suggests customers do not all, at least initially, share the bank's interest in promoting new communication technologies. The majority of customers exhibit risk concerns regarding Internet banking and are suspicious of new technology when first introduced (Laukkanen et al., 2008, Grabner-Kräuter and Faullant, 2008). However, the majority of Internet banking adopters are middle-aged males with above average incomes, who are also

\footnotetext{
${ }^{19}$ Note this is a different point than that suggested in Table 1, which refers to multinational operation by SMEs rather than their position in supply chains.
} 
well-educated and familiar with technology (Akinci et al., 2004; Ozdemir et al., 2008). In China, many SME owners and managers do not fall into this category and one would not, therefore, anticipate they would welcome and use new communication channels, in turn, at least in a restricted communicative sense, leading to a positive determination regarding the development of such banking services.

Table 5 sets out the communication channels used by SMEs with their banks.

Table 5: Comparison of SMEs communications with banks

\begin{tabular}{|c|c|c|c|c|c|c|c|c|c|c|}
\hline & \multicolumn{2}{|c|}{ China } & \multicolumn{2}{|c|}{ UK* } & \multicolumn{2}{|c|}{ USA* } & \multicolumn{2}{|c|}{ Germany* } & \multicolumn{2}{|c|}{ Hong Kong* } \\
\hline & Rank & $\%$ & Rank & $\%$ & Rank & $\%$ & Rank & $\%$ & Rank & $\%$ \\
\hline Visit branch & 1 & 69 & 4 & 43 & 2 & 78 & 3 & 62 & 4 & 47 \\
\hline Telephone & 2 & 51 & 1 & 84 & 1 & 88 & 1 & 85 & 1 & 96 \\
\hline Email or internet banking & 3 & 11 & 2 & 58 & 3 & 57 & 2 & 76 & 2 & 66 \\
\hline Write a letter to bank & 4 & 5 & 3 & 54 & 4 & 29 & 4 & 30 & 3 & 50 \\
\hline
\end{tabular}

*Approximated numbers obtained from Berry (2006, page 44) and China data from own survey.

The data suggests that Chinese SMEs still favour traditional forms of communication at the time of collecting data. ${ }^{20}$ In particular they still prefer visiting the local branch. One might infer from this that the finding reflects the perceived significance of guanxi in the Chinese context, and that this provides a countertendency to the expectation based on the general characteristics of SME managers and owners. One might also note that writing a letter to a bank would be unusual in a Chinese cultural setting. In other countries, the most popular communication channel was via telephone, ranging from $96 \%$ to $84 \%$ in usage. Only $11 \%$ of

\footnotetext{
${ }^{20}$ In recent years, internet banking is exceptionally popular among young generation and professionals.
} 
Chinese SMEs use e-mail or Internet banking and this is significantly lower than the comparators, where the figure ranges from $76 \%$ in Germany to $57 \%$ in the USA.

\section{Satisfaction with banks}

One key measure here is an SME's expressed satisfaction with their banks service performance. A range of theory is relevant here. Service Management Theory (Grönroos, 1994) suggests that the customer's perception of service quality is determined by a combination of the services actually provided (a technique dimension) and the interaction between customer and seller (a functional dimension). The Relationship Marketing Paradigm emphasises the whole process, from attracting to maintaining, and then enhancing the customer relationship, with further consequences for the firm's reputation and image (Gummesson, 1996). In line with these theories, literature on the SME-bank relationship finds that SMEs initially have high expectations of their banks. They expect the bank to understand their needs, to treat them as a unique case, rather than in a standardised way (Lam and Burton, 2006), and they appreciate a bespoke service delivered by a bank officer advice able to constructively evaluate their business potential (Binks and Ennew, 1997; Adamson et al., 2003). As such, they expect something akin to the German model of relationship lending. Vegholm (2011) confirms that SME perception of their bank is influenced by a bank officers' ability to adapt to SME clients' needs and to provide useful advice. In addition, as the majority of SMEs are dependent on bank financing, the availability of bank loans is also closely associated with high degree of satisfaction (Vegholm, 2011).

Table 6 sets out our findings regarding SME satisfaction with the services provided by their $\operatorname{bank}(\mathrm{s})$. 


\begin{tabular}{|c|c|c|c|c|c|}
\hline & $\begin{array}{l}\text { China } \\
\text { Mean }\end{array}$ & $\begin{array}{l}\text { UK* } \\
\text { Mean }\end{array}$ & $\begin{array}{l}\text { USA* } \\
\text { Mean }\end{array}$ & $\begin{array}{c}\text { Germany* } \\
\text { Mean }\end{array}$ & $\begin{array}{c}\text { Hong } \\
\text { Kong* } \\
\text { Mean }\end{array}$ \\
\hline Overall quality of service & 3.3 & 4.0 & 4.4 & 4.0 & 3.7 \\
\hline Availability of finance & 3.4 & 3.9 & 4.2 & 3.7 & 3.6 \\
\hline Range of services offered & 3.4 & 3.9 & 4.3 & 3.7 & 3.7 \\
\hline Competence of staff & 3.2 & 3.9 & 4.3 & 3.8 & 3.7 \\
\hline Speed and efficiency of services & 3.3 & 3.9 & 4.3 & 3.8 & 3.7 \\
\hline Main contact & 3.7 & 3.9 & 4.3 & 3.8 & 3.8 \\
\hline $\begin{array}{l}\text { Level of understanding of your } \\
\text { business }\end{array}$ & 3.3 & 3.6 & 3.9 & 3.7 & 3.5 \\
\hline Charges or tariffs & 3.1 & 3.0 & 3.8 & 2.9 & 3.1 \\
\hline Overall & 3.3 & 3.8 & 4.2 & 3.7 & 3.6 \\
\hline
\end{tabular}

These items were measured by a 5-point Likert-scale from 1 "Very dissatisfied" to 5 "Very satisfied". The table indicates that, apart from the items "Main contact" and "Charges or tariffs", the China data exhibits a significantly lower mean for each item than the comparators. We can further classify the items into four categories: (1) Finance related satisfaction (i.e. “Availability of finance”); (2) Services related satisfaction (i.e. "Range of services offered" and "Speed and efficiency of services”); (3) Bank staff related satisfaction (i.e. “Competence of staff” and "Level of understanding of your business”) (4) Overall satisfaction (i.e. “Overall quality of service” and “Overall”).

The first three categories impact on the scores for overall satisfaction. If we refer back to some of the context claims set out in Section 2, the significantly lower scores here indicate 
that one reason for the reported rapid shifting by SMEs between banks and also the use of multiple banks in China is a poor quality of service that fails to meet expectations. One might infer then that in terms of banking services, Chinese banks are deficient.

\section{Bank financing problems}

Table 7 sets out the survey results for Chinese SMEs seeking external finance and places this data with the comparators. 
Table 7: Comparison of banks as a source of finance

\begin{tabular}{|c|c|c|c|c|c|}
\hline & China & $\mathrm{UK}^{*}$ & USA* & Germany* & Hong Kong* \\
\hline & $\%$ & $\%$ & $\%$ & $\%$ & $\%$ \\
\hline External finance sought in last 3 years** & 63 & 17 & 24 & 19 & 22 \\
\hline From: Main bank & 50 & 37 & 43 & 57 & 54 \\
\hline Other source & 19 & 54 & 36 & 27 & 23 \\
\hline Both & 31 & 9 & 21 & 16 & 23 \\
\hline Successful in full & 34 & 89 & 92 & 81 & 80 \\
\hline Successful in part & 48 & 9 & 2 & 3 & 5 \\
\hline Refused by financier(s) & 16 & 0 & 0 & 5 & 7 \\
\hline Refused by SME & 2 & 0 & 2 & 3 & 2 \\
\hline Did not know & 0 & 2 & 4 & 8 & 6 \\
\hline
\end{tabular}

**For China, it meant between 2006/09 as we collected data in 2009/10; for other countries, it should be earlier than 2006 but Berry did not indicate it. 
The findings indicate that over a 3 year period the demand for external finance by Chinese SMEs was significantly higher than that for the comparators. The data indicates that Chinese SMEs are far more likely to seek finance than their counterparts and significantly less likely to succeed in obtaining that finance. This finding is in line with other empirical studies of the availability of finance in China (see Gregory et al., 2000; Zeng, 2007). The finding highlights a potential funding gap. This gap is longstanding, a World Bank survey published in 2003 found that only $6.63 \%$ of fixed assets and $9.65 \%$ of working capital of SMEs in China were financed by bank credit (cited in Yao and Yueh, 2009). A more recent report by Deloitte found that $70 \%$ of Chinese SMEs still face a finance gap (Deloitte, 2011). According to the 2013 Survey on the Chinese Banking Industry 'small loans' still only accounted for $14.6 \%$ of the market in $2012 .{ }^{21}$ Given the dynamism of the Chinese economy and the increasing emphasis on the need to diversify the economy in the wake of the global financial crisis, this gap must be considered a matter of concern. According to the SMEs 2013 Annual Report, Chinese SMEs constitute $99.7 \%$ of registered enterprises, provide $80 \%$ of employee opportunities in cities/towns, and contribute $60 \%$ of gross domestic product (GDP), $50 \%$ of tax revenues, $65 \%$ of patents, $75 \%$ of technology innovations and $80 \%$ of new products. $^{22}$ This concern is, however, one that is only partially recognized by Chinese SMEs. Table 8 suggests a series of ranked concerns for SMEs and find that access to finance is ranked only 6 of 9 different concerns. This, however, is a more central concern than is the case for the comparators. The findings are based on a question using a 10-point Likert-scale from 1 “Least important” to 10 "Very important".

\footnotetext{
21 "Survey on the Chinese Banking Industry, 2013” by KPMG.

${ }^{22}$ China Economic Report, Issue 2. 2014, p. 61-67.
} 
Table 8: Comparison of importance of business issues

\begin{tabular}{|c|c|c|c|c|c|c|c|c|c|c|}
\hline & \multicolumn{2}{|c|}{ China } & \multicolumn{2}{|c|}{$\mathrm{UK}^{*}$} & \multicolumn{2}{|c|}{ USA* } & \multicolumn{2}{|c|}{ Germany* } & \multicolumn{2}{|c|}{ Hong Kong* } \\
\hline & Rank & Mean & Rank & Mean & Rank & Mean & Rank & Mean & Rank & Mean \\
\hline $\begin{array}{l}\text { Planning for the future } \\
\text { of the business }\end{array}$ & 1 & 6.7 & 2 & 7.5 & 2 & 8.1 & 1 & 8.0 & 3 & 7.3 \\
\hline Access to new markets & 2 & 6.6 & 6 & 6.0 & 4 & 6.9 & 5 & 6.7 & 4 & 7.1 \\
\hline Achieving enough sales & 3 & 6.5 & 1 & 8.2 & 1 & 8.2 & 2 & 7.8 & 1 & 7.4 \\
\hline $\begin{array}{l}\text { Competition from other } \\
\text { firms }\end{array}$ & 4 & 6.0 & 5 & 6.4 & 5 & 6.8 & 6 & 6.6 & 1 & 7.4 \\
\hline $\begin{array}{l}\text { Finding and retaining } \\
\text { skilled employees }\end{array}$ & 5 & 5.7 & 3 & 6.7 & 3 & 7.0 & 3 & 7.6 & 5 & 6.9 \\
\hline Access to finance & 6 & 5.6 & 8 & 5.7 & 8 & 6.0 & 8 & 5.9 & 8 & 6.3 \\
\hline $\begin{array}{l}\text { Government or other } \\
\text { regulation or red tape }\end{array}$ & 7 & 5.5 & 6 & 6.0 & 7 & 6.1 & 8 & 5.9 & 6 & 6.7 \\
\hline The cost of finance & 8 & 5.4 & 9 & 5.6 & 9 & 5.7 & 7 & 6.1 & 8 & 6.3 \\
\hline The cost of employees & 9 & 5.3 & 4 & 6.5 & 6 & 6.6 & 4 & 7.4 & 6 & 6.7 \\
\hline $\begin{array}{l}\text { A lack of business } \\
\text { support or advice }\end{array}$ & 10 & 5.2 & 10 & 5.0 & 10 & 5.1 & 10 & 5.0 & 10 & 6.1 \\
\hline $\begin{array}{l}\text { The cost of or finding } \\
\text { suitable premises }\end{array}$ & 11 & 3.8 & 11 & 4.6 & 11 & 4.2 & 11 & 3.4 & 11 & 5.8 \\
\hline
\end{tabular}

*Data from Berry (2006, page55) and China data from own survey. Scale: 1= Least important to 10= Very important. 
As a final point here, the findings regarding financing highlighted in Tables 7 and 8 provide some context for the overall satisfaction scores in Table 6. They collectively suggest banking services in China are not meeting either needs or expectations.

\section{Concluding remarks}

Drawing on Berger and Udell’s (2006) conceptual framework, this study identified gaps in bank lending and services to SMEs in China in the context of some relevant comparators, i.e. Germany, the UK and the USA, and Hong Kong followed a stylised comparison. The results reveal that China has developed a banking infrastructure which is equivalent to comparable developed countries. This can be confirmed from the results such as the majority of surveyed Chinese SMEs have multiple banking relationships (though most prefer engaging with stateowned commercial banks), and they have relatively high uptake on a wide variety of banking services. However in terms of the quality of bank services, China is deficient. The findings provide some evidence that there is a funding gap experienced by SMEs in China and that SMEs are poorly served by the current state of the banking system in China. For example, Chinese sample has the lowest score of satisfaction with their banks regarding to overall quality of service, availability of finance, range of services offered, competence of staff, speed and efficiency of services and bank officers’ understanding level of their businesses.

The findings suggest some policy implications. China in particular has a lending system that operates according to state influence and according to guanxi relations, which are rather different than the German relational lending model. SMEs are an important contributor to sustainable growth in China. SMEs exist in a finance and banking environment that is still in 
transition. The lending infrastructure is now more developed and diversified, though still dominated in a de facto sense by the state-owned banks. In 2012, six domestic banks (including 4 state-owned) were among the world top 500 enterprises. ${ }^{23}$ The system has shifted from centralisation to partial decentralisation, from government absolute intervention to indirect intervention and influence. State owned banks still receive favourable treatment from the state. A non-performing loan problem still persists and other forms of bank still experience a discriminatory environment. ${ }^{24}$ The state, however, is committed to addressing the issues. In November 2013, the "Decision on a number of reform issues of the third plenum of the Eighteenth Central Committee of CCP”, determined that private small and medium sized banks /financial institutions may now be created, subject to strict monitoring. ${ }^{25}$ This may prove to be one of the most important financial reforms if it begins to contribute to a reduction in the discriminatory environment currently faced by SMEs. ${ }^{26}$ This, in turn, may begin to affect the currently adverse state of lending services. As such, it would be meaningful for future research to assess the impacts of these financial and institutional changes on lending infrastructure and services to SMEs from different perspectives.

The paper contributes to the body of knowledge in two ways: firstly, our stylised contrast makes China comparable with four other nations/regions to assess similarities and divergences in the lending facilities and banking services to SMEs, though there is a gap with regards to the points of data collection. Secondly, our in-depth discussions in the context of government policies, financial infrastructure, SME credit availability, and the intricacies of

\footnotetext{
23 “10 year 'Nirvana’ of China’s banking sector”, China Economic Weekly, January 6, 2013. There is still only one big private bank - Minsheng Bank - established in 1996.

${ }^{24}$ NPLs rate dramatically reduced from $23.6 \%$ at the end of 2002 to $1.56 \%$ by the end of 2012 (China Economic Weekly, January 6, 2013) which results by the fact that the government pumped large new funds into SOCBs and the latter sold their NPLs to individuals at non-market price.

25 "The gate to private banks is opening soon and banking sector is entering an era of differential operations", Securities Times newspaper, March 10, 2014.

26 “The highlights of China’s banking reforms in 2014”, Financial Times (FT. Chinese), February 11, 2014.
} 
the SME-bank relationship between China and the comparators provides insights of the similarities and divergences. However as with many other studies, this paper has a number of limitations with which the generalisation of the findings might be premature: (1) as noted in Section 3, the nature of Chinese sample is hardly justified to be representative considering China is geographically highly diverse in terms of economic and social development, as such finding generalisation could be problematic; (2) the analysis pattern had to be in line with Berry's publication because of the nature of the study and therefore more advanced test (e.g. ANOVA, regression) could not be carried out. As such, the findings suggesting significant differences between China and other countries can only be presented in general term.

\section{Acknowledgement}

The authors would like to thank Jamie Morgan, Paul Houghton and Jill Webb for kind help and constructive comments. 


\section{References}

Adamson, I., Chan, K-M. and Handford, D. (2003) 'Relationship marketing: customer commitment and trust as a strategy for the smaller Hong Kong corporate banking sector', International Journal of Bank Marketing, Vol. 21 No. 6/7, pp. 347-358.

Akinci, S., Aksoy, S. and Atilgan, E. (2004) 'Adoption of Internet banking among sophisticated consumer segments in an advanced developing country', The International Journal of Bank Marketing, Vol. 22 No. 3, pp. 212-232.

Allen, F., Qian, M. and Qian, J. (2005) 'Law, finance, and economic growth in China', Journal of Financial Economics, Vol. 77 No. pp. 57-116.

Berger, A. and DeYoung, R. (2001) 'The effects of geographic expansion on bank efficiency’, Journal of Financial Services Research Vol. 19 No. 2, pp. 163-184.

Berger, A. and Udell, G. (2006) 'A more complete conceptual framework for SME finance', Journal of Banking \& Finance, Vol. 30 pp. 2945-2966.

Berger, A., Hasan, I. and Zhou, M. (2009) 'Bank ownership and efficiency in China: What will happen in the world's largest nation?’, Journal of Banking \& Finance, Vol. 33 pp.113-130.

Berry, A. (2006) 'Banks, SMEs and accountants: an international study of SMEs' banking relationships’, ACCA Research Report No. 95.

Berry, A., Grant, P. and Jarvis, R. (2004) 'European bank lending to the UK SME sector: An investigation of approaches’, International Small Business Journal, Vol. 22 No. 2, pp. 115-130.

Binks, M.R. and Ennew, C.T. (1997) 'The relationship between UK banks and their small business customers’, Small Business Economics, Vol. 9, pp. 167-178.

Bolton Committee Report. (1971) 'Bolton Committee Report, Report of the committee of inquiry on small firms', Cmnd Vol. 4811. London: HMSO.

CBRC. (2013). China Banking Regulatory Commission Annual Report. Beijing:CBRC.

Chong, T.T., Lu, L. and Ongena, S. (2013) 'Does banking competition alleviate or worsen credit constraints faced by small- and medium-sized enterprises? Evidence from China', Journal of Banking \& Finance Vol. 37, pp. 3412-3424.

Collis, J. and Jarvis, R. (2002) 'Financial information and the management of small private companies’, Journal of Small Business and Enterprise, Vol. 9 No. 2, pp. 100-110.

Cosh, A. and Hughes, A. (2000) 'British enterprise in transition: growth innovation and public policy in the small and medium sizes enterprise sector 1994-1999’, ESRC Centre for Business Research. Cambridge: University of Cambridge,

Dana, L.P. (1999) 'Small business as a supplement in the People's Republic of China (PRC), Journal of Small Business Management, Vol. 37 No. 3, pp. 76-80.

Dana, L.P. (2002) 'When Economies Change Paths Models of Transition in China, the Central Asian Republics, Myanmar \& the Nations of Former Indochine Francaise'. London: World Scientific Publishing Co. Pte. Ltd.

Dana, L.P. (2013) 'Informal economy entrepreneurship and policy implications'. In: Thai, M.T.T and Turkina, E., ed. Entrepreneurship in the Informal Economy. New York and London: Routledge, 2013, pp. 259-268.

Davies, H. (1995) China Business: Context and Issues, Hong Kong: Longman Asia Ltd.

Deloitte. (2011) 'New thought, new model: Development of SMEs business in Chinese commercial banks', available at: www.docin.com/p-315187712.html (accessed 02/07/12). 
Elsas, R. and Krahnen, J.P. (1998) 'Is relationship lending special? Evidence from credit-file data in Germany’, Journal of Banking and Finance, Vol. 22, pp. 1283-1316.

Fletcher, M. (1994) 'How bank managers make lending decisions to small firms', 17th Institute of UK Banking Small Firms and Policy and Research Conference.

Fraser, S. (2004) 'Finance for Small and Medium-sized Enterprises: A Report on the 2004 UK Survey of SME Finances', Warwick: Centre for Small and Medium-Sized Enterprises.

Fu, X. and Heffernan, S. (2009) 'The effects of reform on China's bank structure and performance', Journal of Banking \& Finance, Vol. 33, pp. 39-52.

Ghosh, S. (2006) 'Did financial liberalization ease financing constraints? Evidence from Indian firm-level data’, Emerging Markets Review, Vol. 7, pp. 176-190.

Grabner-Kräuter, S. and Faullant, R. (2008) 'Consumer acceptance of internet banking: the influence of internet trust’, International Journal of Bank Marketing, Vol. 26 No. 7, pp. 483-504.

Gregory, N., Tenev, S. and Wagle, D.M. (2000) China's Emerging Private Enterprises: Prospects for the New Century. Washington: International Finance Corporation.

Grönroos, C. (1994) 'From marketing mix to relationship marketing: towards a paradigm shift in marketing', Management Decision, Vol. 32 No. 2, pp. 4-20.

Gummesson, E. (1996) 'Relationship marketing and imaginary organizations: a synthesis', European Journal of Marketing, Vol. 30 No. 2, pp. 31-44.

Hagendorff, J., Collins, M. and Keasey, K. (2007) 'Bank deregulation and acquisition activity: the cases of the US, Italy and Germany', Journal of Financial Regulation and Compliance Vo. 15 No. 2, pp. 199-209.

Harhoff, D. and Körting, T. (1998) 'Lending relationships in Germany - Empirical evidence from survey data', Journal of Banking \& Finance, Vol. 22, pp.1317-1353.

Haselmann, R. (2006) 'Strategies of foreign banks in transition economies', Emerging Markets Review, Vol. 7, pp. 283-299.

Heffernan, S. (2006) 'UK bank services for small business: How competitive is the market?' Journal of Banking \& Finance, Vol. 30, pp. 3087-3110.

Hou, X. and Wang, Q. (2013) 'Implications of banking marketization for the lending channel of monetary policy transmission: Evidence from China', Journal of Macroeconomics, Vol. 38, pp. 442-451.

Hussain, J., Millman, C. and Matlay, H. (2006) 'SME financing in the UK and in China: a comparative perspective’, Journal of Small Business and Enterprise Development, Vol. 13 No. 4, pp. 584-599.

Iyer, R. and Puri, M. (2012) 'Understanding bank runs: The importance of depositor-bank relationships and networks', American Economic Review, Vol. 102 No. 4, pp. 1414-1445.

Kakes, J. and Sturm, J.E. (2002) 'Monetary policy and bank lending: Evidence from German banking groups', Journal of Banking \& Finance, Vol. 26, pp. 2077-2092.

Klapper, L. (2006) 'The role of factoring for financing small and medium enterprises', Journal of Banking \& Finance, Vol. 30, pp. 3111-3130.

Krahnen, J.P. and Elsas, R. (2004) 'Universal banks and relationships with firms', in: Krahnen, JP and Schmidt RH (eds) The German Financial System, Oxford: Oxford University Press.

Kwan, S.H. (2006) 'The X-efficiency of commercial banks in Hong Kong', Journal of Banking \& Finance, Vol. 30, pp. 1127-1147.

Lam, R. and Burton, S. (2005) 'Bank selection and share of wallet among SMEs: Apparent differences between Hong Kong and Australia’, Journal of Financial Services Marketing, Vol. 9 No. 3, pp. 204-213.

Lam, R. and Burton, S. (2006) 'SME banking loyalty (and disloyalty): A qualitative study in Hong Kong’, International Journal of Bank Marketing, Vol. 24 No. 1, pp. 37-52. 
Laukkanen, P., Sinkkonen, S. and Laukkanen, T. (2008) 'Consumer resistance to internet banking: Postponers, opponents and rejectors', International Journal of Bank Marketing, Vol. 26 No. 6, pp. 440-455.

Lehmann, E. and Neuberger, D. (2001) 'Do lending relationships matter? Evidence from bank survey data in Germany’, Journal of Economic Behavior and Organization, Vol. 45 No. 4, pp. 339-359.

Lin, N. (2001) 'Guanxi: A Conceptual Analysis', in So, A.Y., Lin, N., Poston, D.L. (eds), The Chinese triangle of mainland China, Taiwan, and Hong Kong: Comparative institutional analyses, Greenwood Press.

Lu, Z., Zhu, J. and Zhang, W. (2012) 'Bank discrimination, holding bank ownership, and economic consequences: Evidence from China’, Journal of Banking \& Finance, Vol. 36 No. 2, pp. 341-354.

Morgan, J. and Sheehan, B. (2015) 'The concept of trust and the political economy of John Maynard Keynes, illustrated using central bank Forward Guidance and the democratic dilemma in Europe’, Review of Social Economy, Vol. 73 No. 1, pp. 113-137.

Mullineux, A.W. (1994) 'Small and Medium-sized Enterprise Financing in the UK: Lessons from Germany’, London: Anglo-German Foundation Report,

Newman, A., Sailesh, G. and Hilton, B. (2012) 'Applicability of financial theories of capital structure to the Chinese cultural context: A study of privately owned SMEs', International Small Business Journal, Vol. 30 No. 1, pp. 65-83.

Norden, L. and Weber, M. (2010) 'Credit line usage, checking account activity, and default risk of bank borrowers', The Review of Financial Studies, Vol. 23 No. 10, pp.3665-3699.

OECD. (2003), Bank Profitability- Financial Statements of Banks. Paris: Organisation for Economic Co-operation and Development.

Ongena, S. and Smith, D.C. (2000) 'What determines the number of bank relationships? Cross-country evidence', Journal of Financial Intermediation, Vol. 9, pp. 26-56.

Ongena, S., Tümer-Alkan, G. and Westernhagen, N. (2012) 'Creditor concentration: An empirical investigation’, European Economic Review, Vol. 56, pp. 830-847.

Ozdemir, S., Trott, P. and Hoecht, A. (2008) 'Segmenting internet banking adopter and nonadopters in the Turkish retail banking sector', International Journal of Bank Marketing, Vol. 26 No. 4, pp. 212-236.

Podpiera, R. (2006) 'Progress in China's banking sector reform: Has banking behavior Changed?’, IMF Working Paper No. 06/71.

Poutziouris, P., Wang, Y. and Chan, S. (2002) 'Chinese entrepreneurship: The development of small family firms in China', Journal of Small Business and Enterprise Development, Vol. 9 No. 4, pp. 383-399.

Quack, S. and Hildebrandt, S. (1995) 'Hausbank or Fournisseur? Bank services for small and medium sized enterprises in Germany and France’, Working paper, Berlin: Social Science Research Center.

Santikian, L. (2014) 'The ties that bind: Bank relationships and small business lending', Journal of Financial Intermediation, Vol. 23 No. 2, pp. 177-213.

Schenk, C.R. (2002) 'Banks and the emergence of Hong Kong as an international financial Center', Journal of International Financial Markets, Institutions and Money, Vol. 12, pp. 321-340.

Scott, J.A. and Dunkelberg, W.C. (2010) 'Competition for small firm banking business: Bank actions versus market structure', Journal of Banking \& Finance, Vol. 34, 2788-2800.

Singh, F. and Kaur, M. (2015) 'Why exporting SMEs switch banks', Global Business Review, Vol.16 No. 4, pp. 652-664. 
Siu, W., Lin, T., Fang, W. and Liu, Z. (2006) 'An institutional analysis of the new product development process of small and medium enterprises (SMEs) in China, Hong Kong and Taiwan', Industrial Marketing Management, Vol. 35, pp. 323-335.

Tan, J., Yang, J. and Veliyath, R. (2009) 'Particularistic and system trust among small and medium enterprises: A comparative study in China's transition economy’, Journal of Business Venturing, Vol. 24, pp. 544-557.

Vegholm, F. (2011) 'Relationship marketing and the management of corporate image in the bank-SME relationship’. Management Research Review, Vol. 34 No. 3, pp. 325-336.

Wong, Y.H. and Chan, R.Y. (1999) 'Relationship marketing in China: Guanxi, favouritism and adaptation', Journal of Business Ethics, Vol. 22, pp. 107-118.

Wu, G. (2011) 'Survey on current Wenzhou informal lending market', Financial Industry (in Chinese). August: pp. 25-27.

Wu, J., Song, J. and Zeng, C. (2008) 'An empirical evidence of small business financing in China', Management Research News, Vol. 31 No. 12, pp. 959-975.

Xiao, L. (2011) 'Financing high-tech SMEs in China: A three-stage model of business development', Entrepreneurship \& Regional Development, Vol. 23 No. 3-4, pp. 217-234.

Yao, Y. and Yueh, L. (2009) 'Law, finance, and economic growth in China: An introduction’, World Development, Vol. 37, pp. 753-762.

Yeung, G. (2009) 'Hybrid property, path dependence, market segmentation and financial exclusion: the case of the banking industry in China', Transactions of the Institute of British Geographers, Vol. 34 No. 2, pp. 177-194.

Yeung, G., He, C. and Liu, H. (2012) 'Centralization and marginalization: The Chinese banking industry in reform', Applied Geography, Vol. 32, pp. 854-867.

Zeng, Z. (2007) 'Strategy of enhancing SME finance management', Caikuaitongxun (Finance Edition) (in Chinese) November: pp. 25-26.

Zhang, G. (2008) 'The choice of formal or informal finance: Evidence from Chengdu, China', China Economic Review, Vol. 19, pp. 659-678.

Zhang, J., Wang, L. and Wang, S. (2012) 'Financial development and economic growth:

Recent evidence from China', Journal of Comparative Economics, Vol. 40, pp. 393-412.

Zhou, W. (2009) 'Bank financing in China's private sector: The payoffs of political capital', World Development, Vol. 37 No. 4, pp. 787-799. 


\section{Summary of Revisions}

We would like to express our deepest gratitude for anonymous referees for kind review of our paper, and particularly for the Reviewer 3 for the specific, constructive and directive comments which have helped us to revisit/revise our work and lead to significant improvement. The summary of the actions taken in the light of the Reviewer 3 is as follow:

\begin{tabular}{|c|c|c|}
\hline & Reviewer 3 Comments & Replies and Action Taken \\
\hline 1. & $\begin{array}{l}\text { I find the analytical technique used in this study } \\
\text { too simple perhaps, due to the nature of Berry's } \\
\text { data employed in this study ...... I suggest the } \\
\text { authors use test of differences (ANOVA) to help } \\
\text { them identify the differences properly. Similarly, } \\
\text { test of differences (ANOVA) can be employed to } \\
\text { re-analyse the results contained in Tables } 5 \text { \& } 7 .\end{array}$ & $\begin{array}{l}\text { Thank you for this point. However, because our } \\
\text { comparative data are in aggregate form only making } \\
\text { the analysis using ANOVA with Chinese data which } \\
\text { is at firm level impossible. The nature of the study } \\
\text { also suggests it is appreciate to apply for a stylised } \\
\text { data analysis pattern. }\end{array}$ \\
\hline \multirow[t]{3}{*}{2.} & \multirow{3}{*}{$\begin{array}{l}\text { The discussion of the results appears sketchy and } \\
\text { superficial. ...For example, in page 25, the } \\
\text { authors write "The high levels of treasury services } \\
\text { and mortgage access also indicate that Chinese } \\
\text { SME owners also use their businesses as security } \\
\text { for property and financial assets. This may prove } \\
\text { problematic at a later stage if China suffers a non- } \\
\text { performing loan crisis based on any property and } \\
\text { other asset speculation" What does this mean? I } \\
\text { suggest that the authors develop this sentence and } \\
\text { explain what it means. Similarly, the authors find } \\
\text { the use "branch visit" is predominant way of } \\
\text { communicating in China but didn't explain what } \\
\text { that implies for fast and quality service delivery? } \\
\text { Again, the authors find overall satisfaction in } \\
\text { China to be lower compared to other countries. I } \\
\text { suggest the authors provide explanation for the } \\
\text { results to enable readers assess the overall } \\
\text { contribution of the paper. }\end{array}$} & $\begin{array}{l}\text { 1. The sentence "The high levels of treasury } \\
\text { services and mortgage access also indicate } \\
\text { that Chinese SME owners also use their } \\
\text { businesses as security for property and } \\
\text { financial assets. This may prove problematic } \\
\text { at a later stage if China suffers a non- } \\
\text { performing loan crisis based on any property } \\
\text { and other asset speculation" has been revised } \\
\text { by providing more explanations. }\end{array}$ \\
\hline & & $\begin{array}{l}\text { 2. The recent development in bank } \\
\text { communication technology has been updated } \\
\text { by adding a note. }\end{array}$ \\
\hline & & $\begin{array}{l}\text { 3. We think the reasons for overall lower } \\
\text { satisfaction in China have been shown in our } \\
\text { in-depth discussion of the results. }\end{array}$ \\
\hline 3. & $\begin{array}{l}\text { The conclusion section appears sketchy. I suggest } \\
\text { the authors re-write this section and incorporate } \\
\text { the following: a) summary of key results; b) } \\
\text { contribution and managerial implications of the } \\
\text { paper; and limitations of the paper. }\end{array}$ & $\begin{array}{l}\text { We have revised the conclusion section in the light } \\
\text { of your comments. Accordingly, the revision of } \\
\text { conclusion includes a) summary of key results; b) } \\
\text { implications of the findings; c) contributions and } \\
\text { limitations of the paper. }\end{array}$ \\
\hline 4. & $\begin{array}{l}\text { Minor Comment: } \\
\text { The authors write the following sentence in the } \\
\text { abstract "This study adopts stylised comparisons } \\
\text { with Germany, the UK and the USA, and Hong } \\
\text { Kong. The results emphasise a complex of causal } \\
\text { relationships between government policies, } \\
\text { financial infrastructure, SME credit availability, } \\
\text { and the intricacies of the SME-bank relationship } \\
\text { in China" } \\
\text { I think this sentence is an exaggeration as no } \\
\text { causality test was carried out in this paper and } \\
\text { hence they have no evidence to claim that. }\end{array}$ & $\begin{array}{l}\text { This sentence has been revised and the words } \\
\text { "causal relationships" have been removed. }\end{array}$ \\
\hline
\end{tabular}

